Jakub Dziadkowiec

\title{
Poszukiwanie sensu we Wszechświecie emergentnym
}

\section{Wprowadzenie}

Jakkolwiek dyskusje na temat emergencji toczą się dziś głównie w ramach filozofii analitycznej - niedawno uważanej jeszcze za programowo anty-metafizyczną - to korzenie tego pojęcia sięgają prób uprawiania metafizyki par excellence. Emergentyzm Brytyjski, powstały w latach dwudziestych ubiegłego stulecia, wypracował pojęcie emergencji w kontekście szeroko zakrojonej metafizyki, rozumianej jako próba syntezy wyników wszelkiego możliwego doświadczenia - zaczynając od naukowego i filozoficznego, przez zdroworozsądkowe, kończąc na praktykach artystycznych i religijnych. Dzisiaj emergencja zyskuje sobie coraz więcej zwolenników wśród przedstawicieli nauk szczegółowych. Jej terminologia pojawia się w słownikach takich nauk jak: fizyka, biologia, neurologia, nauki społeczne, urbanistyka, cybernetyka, ekonomia, sztuczna inteligencja, etc.

Taki stan rzeczy niesie ze sobą niebezpieczeństwo pewnych nieporozumień. Główne zagrożenie dla stosowanego dzisiaj pojęcia emergencji można wyrazić słowami ks. M. Hellera: „Z chwilą, gdy jakieś pojęcie wchodzi w szerszy obieg, jego znaczenie natychmiast 
się rozmywa. Dotyczy to także pojęć filozoficznych. W takiej sytuacji często tracą one swoje pierwotne techniczne znaczenia (jeżeli kiedykolwiek je miały) i stają się nosicielami sloganowych skojarzeń" 1 .

Pierwszym zadaniem niniejszej pracy jest wykazanie, że termin „emergencja” posiada swoje pierwotne techniczne znaczenie, a nie jest tylko synonimem dla słów: ewolucja, rozwój, nowość, zaskoczenie, emanacja, itp. Chcąc rzetelnie - a nie sloganowo - stosować pojęcie emergencji tak w filozofii, jak i w naukach szczegółowych, należy wziąć pod uwagę jego uwikłanie w tradycję, sięgająca przynajmniej połowy XIX wieku.

Zadanie drugie polega na wykazaniu, iż rezultaty pewnych badań z obszaru nauk ścisłych (głównie nauk fizycznych) nie tylko nie wykluczają możliwości ich filozoficznej interpretacji w duchu doktryny emergencji, lecz w pewien sposób sprzyjają takiej sposobności. Mowa tu głównie o zjawisku dekoherencji w mechanice kwantowej oraz o modelach kreacji Wszechświata jako całości z punktu osobliwości początkowej. Wnioski z tych badań skonfrontowane zostaną z ustalonymi wcześniej warunkami emergencji filozoficznej. Wreszcie jako ostatni poruszony zostanie problem Boga w perspektywie świata emergentnego. Konsekwencje takiego podejścia rzutują na relację Stwórca-stworzenie, na charakter Jego działań w obrębie przyrody, jak i na status Boga w hierarchicznej ustrukturyzowanej rzeczywistości. Jak pisze J. Życiński: „Bóg stwarza poprzez prawa przyrody i przez kreatywność, która prowadzi do emergencji nowych struktur" ${ }^{2}$. Panenteistyczna wizja Stwórcy $^{3}$, który w znacznej mierze identyfikuje się ze swoim stwo-

${ }^{1}$ M. Heller, Sens życia i sens Wszechświata. Studia z teologii wspólczesnej, Biblos, Tarnów 2008, s. 113.

${ }^{2}$ J. Życiński, Wszechświat emergentny. Bóg w ewolucji przyrody, KUL, Lublin 2009, s. 71.

${ }^{3}$ Panenteizm (gr. pân en Theós - wszystko w Bogu) zakłada taką relację pomiędzy Bogiem a światem, w której nie jest On ani mocno izolowany od świata, ani nie jest z nim utożsamiany. Bóg częściowo uczestniczy w świecie, który jest w Nim zanurzony. Stanowisko panenteistyczne skonstruowane zostało w opozycji zarówno do klasycznego teizmu, jak i nowożytnego pan- 
rzeniem, sprzyja ujednoliceniu całości emergentnej doktryny oraz stanowi jej zwieńczenie. Tym samym pojęcie emergencji jest kolejnym pomostem pomiędzy „nagimi” wynikami badań naukowych a filozoficzną koncepcją Boga.

\section{Filozoficzna relacja emergencji}

Popularne ujęcie emergencji można wyrazić sformułowaniem, że całość jest czymś więcej niż suma swoich części. Jakkolwiek zawarta w nim intuicja nie jest błędna, to jednak, chcąc dotrzeć do źródeł naszego pojęcia, musimy od niej abstrahować. Badania wskazują, że początków pojęcia emergencji należy doszukiwać się w połowie XIX wieku u J.S. Milla ${ }^{4}$. Autor ten, w pracy The System of Logic ${ }^{5}$, odróżnia efekt homopatyczny od efektu heteropatycznego (heteropathic and homopathic effects). Obydwa efekty pociągaja za sobą odpowiednie prawa. Mill twierdzi, że zjawiska, będące wynikiem działania praw homopatycznych, są mechanicznymi konsekwencjami działających w nich sił i nie wykraczają poza obręb domeny, do której należą (np. świata fizykalnego ${ }^{6}$ ). Przeciwnie, zjawiska rządzone przez prawa heteropatyczne nie są rezultatem działania czysto mechanicznego i same należą do domeny wyższej, niż ta, z której pochodzą ich przyczyny. Filozof konkluduje, że zjawiska oparte na prawach i efektach heteropatycznych, będąc zakorzenione w konkretnej dziedzinie rzeczywistości,

teizmu. Zob. hasło „panentheism” w Stanford Encyclopedia of Philosophy: $<$ http://plato.stanford.edu/entries/panentheism $>$.

${ }^{4}$ B. McLaughlin, „The Rise and Fall of British Emergentism”, [w:] M. Bedau, P. Humphreys (eds), Emergence: Contemporary Readings in Philosophy and Science, A Bradford Book, Cambridge 2008, s. 19-59.

${ }^{5}$ J.S. Mill, The System of Logic, Longmans, Greek, Leader, and Dyer, London 1872.

${ }^{6}$ Termin „fizykalny” należy tu odróżnić od terminu „fizyczny”. O ile ten drugi, gdy jest szeroko rozumiany i przeciwstawiany słowu „mentalny”, denotuje całość zjawisk w obrębie świata przyrodniczego, o tyle pierwszy nazywa obszar badań wyznaczony w ramach nauki, jaką jest fizyka. Zob. H.D. Musther, Wprowadzenie do filozofii przyrody, WAM, Kraków 2005, s. $100-107$. 
wykraczają ponad nią i stanowią podstawę pod formułowanie się nowej, wyższej dziedziny.

Kolejni myśliciele odnaleźli w rozróżnieniach Milla na tyle silne narzędzie konceptualne, iż oparli na nim swoje, nie nazwane jeszcze explicite, pojęcie emergencji ${ }^{7}$. Dopiero po trzech dekadach wykorzystany został termin emergencja, którego po raz pierwszy użył G.H. Lewes w pracy The Problems of Life and Mind ${ }^{8}$. Odwołuje się on wprost do dystynkcji Milla, nazywajacc efekt heteropatyczny - emergentnym (emergent), a efekt homopatyczny - wypadkowym (resultant). Jakkolwiek Lewes nie przyczynił się $\mathrm{w}$ znacznym stopniu do rozwoju emergentyzmu, to wprowadzenie terminu emergencja jest jego niewątpliwą zasługą. Jak twierdzi McLaughlin: „«Emergencja» ujmuje wyobrażenie w sposób, którego nie oddaje ani «heteropatyczne prawo», ani «heteropatyczny efekt»" 9 .

Punktem kulminacyjnym historii pojęcia emergencji jest krótki, pięcioletni okres w latach dwudziestych XX wieku. Wówczas to w środowisku anglosaskim pojawił się tzw. Emergentyzm Brytyjski - nurt, który opracowaniu pojęcia emergencji zawdzięcza swoją nazwę. W przeciągu pięciu lat ukazały się trzy najważniejsze książki, prezentujące doktrynę emergentnej ewolucji w możliwie najszerszej, metafizycznej perspektywie. Zaliczane są tu:

- Space, Time, and Deity ${ }^{10}$ - dwutomowe dzieło Samuela Alexandra, będące zestawieniem jego wykładów Gifforda z lat 1916-1918 na uniwersytecie w Glasgow,

${ }^{7}$ Zob. A. Bain, Logic, Book II \& III, London 1870.

${ }^{8}$ G.H. Lewes, The Problems of Life and Mind, vol. 2, Kegan Paul, Trench, Turber, \& Co., London 1875.

${ }^{9}$ B. McLaughlin, dz. cyt., s. 31. Niektórzy jednak twierdzą, jak np. Joachim Metallmann, że Lewes zaszkodził koncepcji emergencji. Polski filozof pisze: „W ten sposób Lewes burzy naprawdę koncepcję wynurzania się"; zob. J. Metallmann, Determinizm w biologii, Biblos, Tarnów 2002, s. 180.

${ }^{10} \mathrm{~S}$. Alexander, Space, Time, and Deity, The Gifford Lectures at Glasgow 1916-1918, Macmillan and Co., London 1927. 
- Emergent Evolution ${ }^{11}$ - praca Conwy'ego Lloyda Morgana, prezentująca ujęcie emergencji z pogranicza psychologii i filozofii,

- The Mind and Its Place in Nature ${ }^{12}$ - obszerne i wysoce analityczne dzieło Charliego Dunbara Broada, w którym m.in. rozważa on stosunek emergentyzmu zarówno do materializmu, jak i mentalizmu.

Pozostałością po pracach Emergentystów Brytyjskich jest wizja rzeczywistości z hierarchiczną strukturą bytów, które należą do kolejnych, zależnych od siebie poziomów ontycznych. Sposób ich powiązania wyznacza relacja emergencji - każdy kolejny szczebel bytowej hierarchii wyłania się z poprzedniego, który stanowi jego „materialną” bazę. Z kolei to, co na danym poziomie ma charakter „duchowy”, jest jakością emergentną (Alexander) lub prawem emergentnym (Broad) ${ }^{13}$. Emergentyści nie zgadzali się jednak w kwestii ilości i charakteru poszczególnych poziomów. Przykładowo dla Morgana fundamentalny poziom stanowi tzw. atomowość (atomicity), uwzględniająca elementarne składniki materii, podczas gdy w systemie Alexandra u podstawy znajduje się Czaso-Przestrzeń (Time-Space), a poziom materialności (materiality) dopiero się z niej wyłania. Inny jest także kres emergencji. Dla pierwszego myśliciela kreatywność świata kończy się na umysłowości (mentality), natomiast w metafizyce drugiego na jakości bóstwa (deity). Broad z kolei abstrahuje od wyliczania poszczególnych szczebli hierarchii bytowej, przyjmując ją za daną,

\footnotetext{
${ }^{11}$ C.L. Morgan, Emergent Evolution, Williams \& Norgate, London 1923.

${ }^{12}$ C.D. Broad, The Mind and Its Place in Nature, Routledge and Kegan Paul, London 1925.

${ }^{13}$ Szczególnie Alexander szeroko stosuje analogię pomiędzy relacją mindbody, odkrywaną w człowieku jako osobie, a relacją, która zachodzi pomiędzy sąsiadującymi poziomami bytowymi. Zob. J. McCarthy, The Naturalism of Samuel Alexander, King's Crown Press, New York 1948, s. 15.
} 
a koncentruje się na ontologicznym badaniu emergentnych praw i możliwości ich zachodzenia ${ }^{14}$.

Pomimo wyżej wymienionych różnic Emergentyzm Brytyjski stanowił nurt jednolity, a jego przedstawiciele komplementarnie rozjaśnili pojęcie emergencji w świetle własnych systemów filozoficznych. Niestety nie doczekali się oni twórczych kontynuatorów i po względnie obszernych debatach w latach trzydziestych i czterdziestych XX wieku, emergencja na kilka dekad usunęła się w cień nowych wyjaśnień redukcjonistycznych. Sytuacja ta zaczęła się zmieniać dopiero od lat siedemdziesiątych wraz z dyskusjami w ramach analitycznie zorientowanej filozofii umysłu, która odwoływała się do pojęcia superweniencji ${ }^{15}$. Aktualnie ta relacja słabej zależności bytowej jest uważana za jeden z warunków koniecznych zachodzenia emergencji. Tym sposobem, problematyka emergencji powróciła do rozważań filozoficznych, szczególnie od początku lat dziewięćdziesiątych ${ }^{16}$. P. Clayton i P. Davies nazywają to zjawisko "the re-emergence of emergence" 17 . Forma emergencji jednak się zmieniła, gdyż dziś nie rozpatruje się jej w kontekście systemu, w którym pełniła określoną funkcję, lecz analitycznymi metodami próbuje się jej nadać nową konotację, najczęściej luźno powiązaną z jej historycznym znaczeniem.

\footnotetext{
${ }^{14}$ Niestety ramy artykułu nie pozwalają na przedstawienie pełniejszej (poza kilkoma hasłowymi stwierdzeniami) charakterystyki Emergentyzmu Brytyjskiego. Więcej na ten temat można znaleźć w następujących pozycjach: B. McLaughlin, dz. cyt.; A. Stephan, „Emergence - A Systematic View on its Historical Facets", [w:] A. Beckerman, H. Flohr, J. Kim (eds), Emergence or Reduction? Essays on the Prospects of Nonreductive Physicalism, Walter de Gruyter 1992, s. 25-47; R. Poczobut, Między redukcja a emergencja. Spór o miejsce umystu w świecie fizycznym, Wydawnictwo Uniwersytetu Wrocławskiego, Wrocław 2009, s 85-110.

${ }^{15}$ Zob. D. Davidson, „Mental Events”, [w:] L. Foster, J.W. Swanson (eds), Experience and Theory, Duckworth, London 1970, s. 79-101; W. Sellars, „Is consciousness physical?", Monist, 64 (1981), s. 66-90.

${ }^{16} \mathrm{~J}$. Kim stwierdza: „Since around 1990, the idea of emergence has been making a big comeback”; zob. J. Kim, „Emergence: Core ideas and issues”, Synthese, 151 (2006), s. 547-559.

${ }^{17} \mathrm{P}$. Clayton, P. Davies (eds), The Re-Emergence of Emergence. The Emergentist Hypothesis from Science to Religion, Oxford 2006.
} 
Przede wszystkim emergencja pojmowana jest jako relacja predykat dwuargumentowy. Trwają spory odnośnie tego, co ma pełnić funkcję argumentów tej relacji (problem tzw. jednostek emergencji). Wśród możliwości wymienia się ${ }^{18}$.

- własności (properties),

- prawa (laws) (Broad),

- jakości (qualities) (Alexander),

- wzorce (patterns),

- poziomy bytowe lub eksplanacyjne (ontological or explanatory levels).

Standardowo wyróżnia się także dwa rodzaje emergencji:

- mocna (ontologiczna) - relacja, opisujacca wyłanianie się jakościowo nowego poziomu bytowego z bardziej podstawowego poziomu; najczęściej podaje się tu dwa przykłady:

- zjawisko świadomości,

- wybrane procesy mechaniki kwantowej.

- słaba (epistemologiczna) - relacja, która polega na podmiotowym spostrzeganiu nowości wyłaniających się poziomów, podczas gdy fundamentalny poziom (zwykle fizyczny) pozostaje niezmienny; przykładami są:

- symulacja sztucznego życia (tzw. gra w życie),

- procesy kognitywne,

- systemy operacyjne,

- ewolucja biologiczna ${ }^{19}$.

\footnotetext{
${ }^{18}$ Zob. R. Poczobut, dz. cyt., s. 71.

${ }^{19}$ Więcej na ten temat, wraz z omówieniem podanych przykładów, pisze D. Chalmers, „Strong and Weak Emergence”, [w:] P. Clayton, P. Davies (eds), dz. cyt., s. 244-256.
} 
Charakterystykę filozoficznej relacji emergencji zakończymy na sformułowaniu listy jej warunków. Trwa dyskusja dotycząca ilości, treści i zasadności przyjmowania poszczególnych przesła$n^{20}{ }^{20}$. Poniżej ograniczymy się do trzech podstawowych warunków, z których jedynie dwa pierwsze są pozbawione kontrowersji, natomiast trzeci jest permanentnie dyskutowany. J. Kim wymienia następujące warunki relacji emergencji ${ }^{21}$ :

1. superweniencja: Własność $M$ superweniuje na własnościach $N_{1}, \ldots, N_{n}$ wtw jeżeli cokolwiek posiada własności $N_{1}, \ldots, N_{n}$, to koniecznie posiada własność $M$.

2. nie-redukowalność: Własność $M$ jest nie-redukowalna do własności $N_{1}, \ldots, N_{n}$ wtw własność M nie może zostać wyprowadzona, nawet $\mathrm{w}$ teorii, $\mathrm{z}$ najbardziej kompletnej wiedzy o własnościach $N_{1}, \ldots, N_{n}$.

3. przyczynowanie odgórne (downward/top-down causation $)^{22}$ : Własności z wyższego poziomu $H$ przyczynują odgórnie własności z niższego poziomu $L$ wtw (1) własności z poziomu $L$ są możliwe do opisania w terminach, stosujących się do własności z poziomu $H,(2)$ prawa z poziomu $L$ są odrębne od praw obecnych na poziomie $H$ oraz (3) własności i prawa z poziomu $H$ muszą być zawarte w tłumaczeniu własności z poziomu $L$.

Ustalenie warunków emergencji filozoficznej dostarcza nam zarówno jej roboczą definicję, jak i narzędzie, za pomocą którego możemy pokusić się o próbę dostarczenia nowej interpretacji

${ }^{20}$ Wśród innych warunków emergencji wymienia się m.in. nowość, nieprzewidywalność, nieaddytywność, niededukowalność; zob. R. Korn, „The Emergence Principle in Biological Hierarchies", Biology and Philosophy, 20 (2005), s. 147-148.

${ }^{21}$ J. Kim, dz. cyt., s. 548.

${ }^{22}$ Definicję przyczynowania odgórnego podaje D.T. Campbell, „'Downward causation' in Hierarchically Organized Biological Systems", [w:] F.J. Ayala, T. Dobzhansky (eds), Studies in Philosophy of Biology, Macmillan Press 1974, s. $179-186$. 
dla znanych zjawisk opisywanych przez fizykę. Przyjrzymy się, jak można wykorzystać emergencję w kwantowym zjawisku dekoherencji oraz w odniesieniu do wybranych modeli kwantowej kosmologii.

\section{Emergentna dekoherencja w mechanice kwantowej}

Zjawisko dekoherencji, które przy odpowiedniej analizie można traktować jako konsekwencję redukcji funkcji falowej, doczekało się licznych interpretacji filozoficznych. Do najpopularniejszych należą:

- kopenhaska, uważana do dziś za ortodoksyjną (Bohr, Heisenberg),

- fali wiodącej lub ukrytych zmiennych (Broglie, Bohm),

- interperetacja von Neumanna (von Neumann, Wheeler, Wigner),

- wielu światów (Everett),

- mechaniki stochastycznej (Nelson).

Problem, do którego odwołują się wyżej wymienione interpretacje, polega na wyjaśnieniu swoistego skoku jakościowego, zachodzącego pomiędzy opisami zachowania się cząstki na poziomie mikroskopowym i makroskopowym. W interpretacji kopenhaskiej — do której ograniczymy dalsze rozważania — ruch cząstki przedstawia jej funkcja falowa, w której zachowanie cząstki jest wyrażone probabilistycznie. Ingerencja obserwatora ze skali makro powoduje detekcję jednej z kanonicznie ze sobą powiązanych wielkości - pędu lub położenia (ew. energii lub czasu) zgodnie z zasadą nieoznaczoności: $\Delta x \Delta p_{x} \geq \frac{\hbar}{2}$. Obserwowana wielkość 
fizyczna traci tym samym swój probabilistyczny charakter i uzyskuje konkretną wartość ${ }^{23}$.

Problem ten można sformułować jako zagadnienie relacji pomiędzy dwoma poziomami ontycznymi: kwantowym i makroskopowym. Jak pokazuje zjawisko dekoherencji, cząstka zachowuje charakter probabilistyczny dopóty, dopóki nie poddana zostaje operacji pomiaru. Wskutek jego przeprowadzenia cząstka uzyskuje zdeterminowaną wartość opisujących ją wielkości fizycznych, których jednak nie można wyznaczyć z dowolnie dużą dokładnością. Widzimy zatem, że dekoherencja zachodzi w wyniku pojawienia się specyficznej relacji pomiędzy poziomem mikro i makro. Relacja ta z pewnością nie jest związkiem ścisłej determinacji, ale nie jest także wynikiem działania zupełnego przypadku. To, w jaki sposób stan cząstki na poziomie mikro wpływa na jej opis z poziomu makro, jest częściowo zakorzenione w jej kwantowym charakterze, lecz nie daje się do niego zredukować - nie istnieje możliwość przewidzenia wartości pędu lub położenia cząstki po pomiarze.

Odnosząc teraz te rozważania do zagadnienia emergencji, zadajmy pytanie: czy relacja między poziomem mikro i makro, na którą wskazuje zjawisko dekoherencji, może zostać nazwana relacją emergencji? Ujmując problem szerzej: czy proces dekoherencji jest zjawiskiem emergentnym? Aby na nie odpowiedzieć, należy kolejno przyjrzeć się - w perspektywie kopenhaskiej interpretacji mechaniki kwantowej - każdemu z wymienionych wcześniej warunków zachodzenia relacji emergencji:

a) superweniencja - relacja ta wydaje się dobrze oddawać związek, jaki zachodzi pomiędzy cząstką w swojej kwantowej, probabilistycznej charakterystyce, a cząstką opisywaną wielkościami

${ }^{23}$ Interpretacja ta zakłada istnienie epistemicznych relacji pomiędzy własnościami obiektów kwantowych, wielkościami fizycznymi oraz wartościami pomiarów, a przez co zalicza się do grupy „bardziej realistycznych” interpretacji QM. Krytyka tego rodzaju ujęć, związana m.in. Z twierdzeniem Kochena-Speckera, uderza w podstawowe założenia dotyczące pomiaru. Zob. Ł. Mścisławski, „Dziwne twierdzenie z teorii kwantów”, Semina Scientiarum, 4 (2005), s. 83-93. 
makroskopowymi; zachodzenie relacji superweniencji implikuje tezę, że jeżeli cząstka posiada kwantowe własności $N_{1}, \ldots$, $N_{n}$, to koniecznie posiada ona też makroskopową własność $M$ (np. pęd lub położenie); problem stanowi tu jednak wyliczenie owych bliżej nieokreślonych własności kwantowych, na których własność $M$ miałaby superweniować ${ }^{24}$.

b) nie-redukowalność - jakkolwiek własność $M$ superweniuje na własnościach $N_{1}, \ldots, N_{n}$, to nie jest do nich redukowalna, przez wzgląd na fundamentalną niemożność wyprowadzenia wartości własności $M$ z nawet najbardziej kompletnej wiedzy o własnościach $N_{1}, \ldots, N_{n}$; a to właśnie ex definitione zakłada nie-redukowalność; okazuje się jednak, że w niektórych przypadkach opis kwantowy stanowi jedyny sposób na wyjaśnienie makroskopowych własności dużych obiektów (np. gwiazda neutronowa czy zjawisko świecenia gwiazd).

c) przyczynowanie odgórne - ingerencja obserwatora z poziomu makro w zachowanie się cząstki na poziomie mikro jest jednym z najlepiej znanych przykładów przyczynowania odgórnego w fizyce; relacja dotyczy jednak przyczynowania odgórnego własności $M$ z poziomu $\mathrm{H}$ względem własności $N_{1}$, $\ldots, N_{n}$ z poziomu $L$, nie natomiast związku pomiędzy obserwatorem a własnościami $N_{1}, \ldots, N_{n}$; powstaje zatem pytanie: w jaki sposób wartość pędu lub położenia uzyskana w zjawisku dekoherencji może wpływać odgórnie na probabilistyczną charakterystykę cząstki na poziomie mikro?

Ostatnie pytanie nie jest bezpodstawne i - o ile uznajemy warunek relacji emergencji - wymaga ono dokładniejszych badań. Nie możemy a priori wykluczyć związku przyczynowania odgórnego, chociażby przez wzgląd na wspomnianą ingerencję

${ }^{24}$ Więcej na temat związków superweniencji z mechaniką kwantową zob. B. McLaughlin, „Emergence and Supervenience”, Intellectica, 25 (2) (1997), s. 25-43; M.P. Seevinck, Parts and Wholes. An Inquiry into Quantum and Classical Correlations, Enschede, Netherlands 2008, s. 223-226. 
obserwatora w układ kwantowy. Pomimo tego problemu, a także trudności wspomnianych w punktach a) i b), należy stwierdzić, że każdy z warunków relacji emergencji, po odniesieniu do zjawiska dekoherencji, uzyskuje podstawę, na której może zostać spełniony. Odpowiedź na pytanie, czy faktycznie jest spełniony, pozostaje kwestią bardziej zaawansowanych, interdyscyplinarnych badań w ramach mechaniki kwantowej, doktryny emergencji i filozofii przyrody.

Sugestia jest taka, że spełniwszy wszystkie trzy (a być może jedynie dwa) powyższe warunki, interpretacja zjawiska dekoherencji w terminologii relacji emergencji jest możliwa. Do zalet takiego ujęcia należy zachowanie autonomii zarówno w domenie świata kwantowego - jego praw i zjawisk, jak i w dziedzinie poziomu makroskopowego. Jednocześnie emergentna dekoherencja podkreśla, że poziomy te są wzajemnie powiązane relacją słabej zależności bytowej (superweniencja), lecz nie mogą zostać do siebie sprowadzone (nie-redukowalność). Natomiast wpływ obserwatora na układ kwantowy wpisuje się w warunek przyczynowania odgórnego, jakie zachodzi pomiędzy dwoma, względem siebie emergentnymi poziomami ontycznymi. Wniosek jest taki, że jakościowa różnica opisywanych praw i struktur pomiędzy poziomem mikroskopowym i makroskopowym sugeruje możliwość zachodzenia mocnej (ontologicznej) relacji emergencji.

\section{Kwantowa emergencja Wszechświata}

Przypatrzmy się teraz, w jaki sposób relacja emergencji może być przydatna w badaniach nad początkami fizycznego Wszechświata $\mathrm{w}$ tym aspekcie, jaki opisuje kosmologia ${ }^{25}$. W przyrod-

${ }^{25}$ Przez kosmologię rozumiemy tutaj fizyczną naukę o Wszechświecie jako całości, o jego globalnych parametrach i strukturze (kosmologia przyrodnicza). Obok niej istnieje jeszcze filozoficzna nauka o tej samej nazwie, zajmująca się pytaniami o początek i koniec świata widzialnego w jego największej skali, o zasady jego porządku, o jego cel i sens oraz o miejsce człowieka w Kosmosie (kosmologia filozoficzna). Zob. M. Heller, Ewolucja kosmosu i kosmologii, PWN, Warszawa 1985; J. Such, M. Szcześniak, A. Szczuciński, 
niczym pytaniu o początek i ewolucję Wszechświata, klasyczna kosmologia, wywodząca się z czasów Galileusza, Keplera i Newtona, napotkała poważne problemy teoretyczne. Zalicza się do nich m.in. problem warunków początkowych, problem horyzontu, płaskości, czy akceleracji Wszechświata ${ }^{26}$. Próbę przezwyciężenia tych trudności we współczesnej fizyce stanowi tzw. kosmologia kwantowa. Jest to projekt połączenia dwóch najważniejszych teorii fizycznych XX wieku: mechaniki kwantowej i ogólnej teorii względności. Za główny cel tego przedsięwzięcia naukowego uważa się sformułowanie teorii, pozwalającej na kwantowanie grawitacji, czyli uzyskanie opisu oddziaływania grawitacyjnego w języku teorii kwantów. W latach siedemdziesiątych i osiemdziesiątych podjęto pierwsze próby skonstruowania takiej teorii, do których zalicza się: model Tryona/Fomina ${ }^{27}$, model Vilenkina ${ }^{28}$ i model Hawkinga-Hartle'a ${ }^{29}$. Natomiast w ostatnich latach, wśród najbardziej zaawansowanych, wymienia się następujące teorie: dynamiczna kauzalna triangulacja ${ }^{30}$, pętlowa grawitacja ${ }^{31}$, teoria superstrun, a także model czasoprzestrzeni, sformułowany przez M. Hellera ${ }^{32}$. Wielość propozycji odzwierciedla nie tylko złożoność problematyki, ale również częściowo spekulatywny charakter ba-

Filozofia kosmologii, Poznań 2000; J. Turek, „Filozofia kosmologii - zarys problematyki", Roczniki filozoficzne, LIII (2) (2005), s. 269-308.

${ }^{26}$ Więcej na ten temat zob. J. Golbiak, Poczatek świata w kosmologii kwantowej, rozprawa doktorska, Katolicki Uniwersytet Lubelski, Lublin 2007.

${ }^{27}$ E.P. Tryon, „Is the Universe a Vacuum Fluctuation?”, [w:] Nature, 246 (1973), s. 396-397.

${ }^{28}$ A. Vilenkin, "Quantum Cosmology and the Initial State of the Universe”, [w:] Physical Review, D37 (1988), s. 888-897.

${ }^{29}$ J.B. Hartle, S.W. Hawking, „Wave Function of the Universe”, [w:] Physics review, D28 (1983), s. 2960-2975.

${ }^{30}$ J. Ambjorn, J. Jurkiewicz, R. Loll, „3d Lorentzian, Dynamically Triangulated Quantum Gravity", [w:] Nuclear Physics Proceedings Supplements, 106 (2002), s. 980-982.

${ }^{31}$ A. Ashtekar, M. Bojowald, J. Lewandowski, „Mathematical structure of loop quantum cosmology", [w:] Advances in Theoretical and Mathematical Physics, 7 (2003), s. 233-268.

${ }^{32} \mathrm{M}$. Heller, Poczatek jest wszędzie. Nowa hipoteza pochodzenia wszechświata, Prószyński i S-ka, Warszawa 2002. 
dań, który zmusza naukowców do formułowania nieempirycznych założeń w oczekiwaniu na rezultaty zderzeń cząsteczek w nieistniejących jeszcze wysokoenergetycznych akceleratorach ${ }^{33}$.

Każda z powyższych teorii dostarcza pewien model początku Wszechświata. Zagadnienie to interesuje nas ze względu na możliwość zbadania, czy proces wyłaniania się Wszechświata z bliżej nieokreślonego, pierwotnego stanu kwantowego można wyrazić $\mathrm{w}$ terminologii relacji emergencji ${ }^{34}$. Innymi słowy: Czy początek Wszechświata w modelach kwantowej kosmologii może być zinterpretowany jako zjawisko emergentne? Czy Wszechświat to twór emergentny? Nie sposób chociażby skrótowo przedstawić tutaj zestawu podstawowych założeń wszystkich wyżej wymienionych teorii. Dlatego, abstrahujacc od najnowszych propozycji, skupimy się na trzech historycznie pierwszych modelach kwantowej kosmologii. W ich krótkim omówieniu posłużymy się wyłącznie jakościowym językiem naturalnym oraz zwrócimy uwage na wskazywany przez te modele stan początkowy Wszechświata:

1. Model Tryona/Fomina - quantum fluctuation: Wszechświat powstaje w wyniku fluktuacji kwantowej próżni stanu zerowych drgań wszystkich pól fizycznych. Zasada nieoznaczoności, wykorzystywana w zjawisku kreacji pary cząstka-antycząstka z elektrodynamiki kwantowej jest ekstrapolowana na Wszechświat jako całość. Zgodnie z zasadą zachowania energii, Wszechświat jest traktowany jako układ zerowy - wszystkie jego wielkości zachowawcze są równe zero. Stan poczactkowy: próżnia kwantowa (zaburzenia pola $\left.\delta g_{\mu v}\right)$ w hipotetycznej, zewnętrznej przestrzeni.

${ }^{33}$ Obecnie Wielki Zderzacz Hadronów w CERN jest w stanie wygenerować energię rzędu $10^{13} \mathrm{eV}$, podczas gdy fizycy oceniają, że do unifikacji oddziaływania grawitacyjnego dochodzi przy energiach planckowskich rzędu $10^{28}$ $\mathrm{eV}$.

${ }^{34}$ M. Szydłowski, J. Golbiak, Kwantowa emergencja Wszechświata, VIII Polski Zjazd Filozoficzny, Warszawa 2008, <http://www.kul.lublin.pl/files/57/working_papers/golbiak_szydlowski_z_2008.pdf $>, 12.01 .2012$. 
2. Model Vilenkina - tunneling Universe: Wykorzystanie znanego z mechaniki kwantowej efektu tunelowania cząstki przez barierę potencjału. Wszechświat tuneluje ze stanu osobliwości początkowej do Wszechświata stacjonarnego (de Sittera). Jego opis jest analogiczny do opisu cząstki punktowej poruszającej się w dołku potencjału $V(a)$. Stan początkowy: jednorodny i izotropowy Wszechświat w osobliwym stanie czasoprzestrzeni.

3. Model Hawkinga-Hartle'a - boundary Universe without boundary: Do opisu Wszechświata autorzy wykorzystuja znaną z mechaniki kwantowej funkcję falową $\Psi$. Stosują oni formalizm całkowania po trajektoriach ${ }^{35}$ dla znalezienia całki opisującej funkcję falową Wszechświata. Stan takiego układu reprezentuje przestrzeń wszystkich zwartych 4-geometrii ${ }^{36}$ (tzw. superprzestrzeń). Próba pozornego uniknięcia stanu początkowego opiera się na analitycznym zabiegu obrotu Wicka, polegającym na przedłużeniu funkcji $t \mathrm{w}$ funkcję it. I w tym modelu odnajdujemy stan początkowy: punkt w przestrzeni o określonej metryce i polach, lecz o zerowej objętości.

Wszystkie trzy powyższe rekonstrukcje wykazują, że analizowane modele kosmologii kwantowej-czasami wbrew intencjom ich autorów - odwołują się do jakiegoś stanu początkowego Wszechświata, z którego znany nam Wszechświat dopiero się wyłania. Tym samym wyrażenie creatio ex nihilo, którym fizycy sygnują filozoficzną doniosłość swoich modeli, jest nadużyciem. Żaden z przedstawionych modeli nie przewiduje powstania Wszechświata z nicości rozumianej filozoficznie - jako negacja bytu, literalne

\footnotetext{
${ }^{35} \mathrm{R}$. Feynman, QED. Osobliwa teoria światla i materii, Państwowy Instytut Wydawniczy, Warszawa 1992.

${ }^{36}$ Zwartość jest jednym z podstawowych pojęć topologii; jej idea wyraża się w twierdzeniu, że w przestrzeni zwartej niektóre własności spełniane lokalnie, są również spełnione globalnie. Model Hawkinga-Hartle'a dotyczy przestrzeni zwartych czterowymiarowych.
} 
nic lub niebyt. Wskazują one raczej - poprzez analogię z procesami mechaniki kwantowej - na istnienie dobrze określonego stanu początkowego, z którego wyłania się wczesny Wszechświat (fluktuacja próżni, tunelująca cząstka, funkcja falowa).

W ten sposób - podobnie jak w przypadku zjawiska dekoherencji - otrzymujemy dwa niesprowadzalne do siebie poziomy ontologiczne: poziom stanu początkowego Wszechświata oraz poziom wczesnego Wszechświata ewoluującego dalej w procesie inflacji. Uznanie, że zachodzi pomiędzy nimi przeskok jakościowy, w którym pojawiają się nowe własności, implikuje możliwość zaistnienia między nimi relacji emergencji. Ponowna analiza jej warunków, tym razem w perspektywie modeli kosmologii kwantowej, wykaże, czy jest to zasadne:

a) superweniencja - charakterystyka stanu podstawowego jako poziomu subwenientnego $\mathrm{w}$ stosunku do superwenientnego stanu wczesnego Wszechświata nie jest logicznie wykluczona. Istnieją jednak poważne przeszkody teoretyczne dotyczące możliwości weryfikacji takiej tezy. Definicja superweniencji zakłada, iż własność $M$ z poziomu wyższego pojawia się z konieczności za każdym razem, gdy na poziomie niższym pojawią się własności $N_{1}, \ldots, N_{n}$. Skoro jednak Wszechświat jest tworem jedynym, to nie istnieje sposób, aby się przekonać, czy ponowne zaistnienie zbioru własności subwenientnych konsekwentnie wygeneruje własność superwenientną. Tym samym nie istnieje metoda lub eksperyment, na podstawie których można by stwierdzić, czy własności wczesnego Wszechświata są połączone relacją superweniencji z własnościami jego stanu początkowego, czy też nie.

b) nie-redukowalność - fizycy postulują, iż prawa i struktury obecne w stanie początkowym Wszechświata zostaną opisane dopiero przez nieznaną jeszcze, odmienną fizykę. Prima facie wydaje się zatem, że własności Wszechświata ze stanu wczesnego muszą diametralnie różnić się od własności jego stanu początkowego, nie mogą zostać z nich wyprowadzone, a więc 
muszą być nie-redukowalne. Istnieje jednak przekonanie, że prawa i struktury dzisiejszej fizyki (opisującej wczesny Wszechświat) zostaną zredukowane do praw i struktur fizyki wielkości planckowskich. Wówczas to znane obecnie prawa będą konsekwencją aplikacji praw przyszłej fizyki do warunków o relatywnie niższych energiach. Z drugiej strony nie przesądza to o ich koniecznej redukowalności, gdyż wówczas dzisiejsza fizyka, opisująca wczesny Wszechświat, mogłaby pełnić funkcje tzw. teorii efektywnej. Istnieją powody, aby sądzić, że już sama możliwość przedstawienia takiej teorii dla pewnej dziedziny rzeczywistości jest świadectwem jej ontologicznej autonomiczności ${ }^{37}$.

c) przyczynowanie odgórne - istnieją racje, by przypuszczać, iż relacja ta stosuje się do problemu emergencji Wszechświata. Trzy zaprezentowane modele kosmologii kwantowej pokazują, że - przy odpowiedniej interpretacji - spełnione są warunki (1) i (3) relacji przyczynowania odgórnego: opis stanu początkowego Wszechświata (poziom L) zachodzi w terminach zapożyczonych ze znanej fizyki (poziom H) i przez analogiczne tłumaczenie. Natomiast możliwość spełnienia warunku (2) odrębności praw z różnych poziomów - zawiera się już w wymogu ich nie-redukowalności.

Każdy z trzech warunków dookreśla formę ewentualnej kwantowej emergencji Wszechświata. Największe trudności przedstawia warunek zaistnienia relacji superweniencji, lecz również nieredukowalność oraz kontrowersyjne przyczynowanie odgórne wymagają bardziej precyzyjnego ujęcia. Nie jest też jasne, czy postulowana tutaj relacja emergencji miałaby występować w swojej mocnej, czy też w słabej formie. Ponownie rodzi się potrzeba bardziej specjalistycznych, interdyscyplinarnych badań, które mogłyby

\footnotetext{
${ }^{37}$ M. Szydłowski, P. Tambor, Kosmologia współczesna jako efektywna teoria Wszechświata - studium metodologiczne. VIII Polski Zjazd Filozoficzny, Warszawa $2008<$ http://www.kul.lublin.pl/files/57/working_papers/szydlowski _tambor_2008f.pdf>, 12.01.2012.
} 
rzucić więcej światła na tę problematykę. Jednakże w przypadku stosunkowo młodej dyscypliny, jaką jest kosmologia kwantowa, sytuacja jest znacznie trudniejsza niż w standardowej mechanice kwantowej. Ograniczenia natury technicznej, unikalność badanego obiektu (Wszechświat jako całość) oraz częściowo spekulatywny charakter dociekań najczęściej uniemożliwiają wyprowadzanie dobrze uzasadnionych hipotez.

Atrakcyjność relacji emergencji w filozoficznych interpretacjach wyników badań kwantowej kosmologii - zawartej chociażby w trzech przedstawionych modelach - polega na tym, że akcentuje ona potrzebę istnienia stanu początkowego, poziomu fundamentalnego, z którego wyłania się Wszechświat opisywany przez dzisiejszą fizykę. Tym samym podejście to ogranicza próby uprawiania krypto-filozofii w teoriach naukowych, odwołujących się chociażby do pojęcia creatio ex nihilo ${ }^{38}$. O ile jednak filozoficzna relacja emergencji ma być użyteczna w badaniach fizycznych, to konieczne jest wypracowanie jej fizycznego odpowiednika, a nie tylko skojarzeniowe odwoływanie się do intuicji, które ze sobą niesie. Wniosek jest taki, że opis początku Wszechświata w wybranych modelach kosmologii kwantowej sugeruje zachodzenie relacji emergencji, lecz wymaga on także wypracowania jej fizycznego odpowiednika.

\section{Emergencja Boga jako sens Wszechświata}

W ostatnim punkcie naszych rozważań zmieniona zostanie płaszczyzna dociekań - po filozoficznej interpretacji wyników badań przyrodniczych pozwolimy sobie teraz na kilka uwag na temat koncepcji Boga, z jaką sprzężona jest doktryna emergencji. Problematyka dekoherencji i kwantowej kosmologii ukazuje, że relacja emergencji daje się stosować do opisu związków zachodzących

\footnotetext{
${ }^{38}$ Należy zwrócić uwagę, że pojęcie to znajduje zastosowanie zarówno w argumentacjach teistycznych (jako moment stworzenia świata przez Boga), jak i ateistycznych (jako naturalistyczne wyjaśnienie procesu stworzenia). Obydwa podejścia są błędne już z metodologicznego punktu widzenia - ich twierdzenia wychodzą poza zakres rozważanej teorii naukowej.
} 
pomiędzy różnymi poziomami świata fizycznego. Istnieją liczne próby aplikowania emergencji do wyjaśnienia zjawisk z kolejnych, wyższych niż fizyczny, poziomów bytowych: procesy chemiczne, zjawisko życia ${ }^{39}$, zagadnienie mind-body, zjawiska społeczne, etc. Argumenty relacji oraz jej charakter są wówczas odpowiednio modyfikowane, lecz podstawowe warunki superweniencji i nieredukowalności zostają zachowane. Całość tych badań ukazuje potrzebę podejmowania prób konstrukcji emergentnej wizji rzeczywistości na wzór metafizyki stworzonej dziewięćdziesiąt lat temu przez Emergentystów Brytyjskich ${ }^{40}$.

Wraz z pytaniem o metafizykę rodzi się pytanie o Boga: jaka jest koncepcja Boga działającego w emergentnym Wszechświecie? Odpowiedzi dostarcza nam perspektywa Boga bliskiego światu, działającego w nim i wzrastającego wraz ze światem, lecz jednocześnie Boga przewyższającego świat, transcendentnego. Emergentny Bóg nie jest już wyłącznie absolutnym stworzycielem świata czy tė̇ jego ukrytą prazasadą. Bliski doktrynie emergencji A. Peacocke pisze, iż „Bóg jest współ-twórcą wraz ze skończonymi czynnikami, wabiąc je bez przymusu i bez uprzednio zdeterminowanych rezultatów" ${ }^{41}$. Swoja koncepcję nazywa teizmem temporalnym, a w zagadnieniu przyczynowania odgórnego doszukuje się on wyjaśnienia charakteru interakcji Boga ze światem.

Jest to bliskie koncepcji A.N. Whiteheada, dla którego Bóg jest „poetą świata, z czułą cierpliwością prowadzącym go przez swoją wizję prawdy, piękna i dobroci" 42 . Zanurzenie Boga w świecie i współ-twórczy charakter Jego działań nie pozostawiają miejsca

${ }^{39}$ Zob. J. Dziadkowiec, „Warunki emergencji biologicznej w świetle sporu emergentyzm-redukcjonizm", Roczniki Filozoficzne, LVII (1) (2009), s. 5-27, gdzie prezentowana jest możliwość rozumienia zjawiska życia jako własności emergentnej.

${ }^{40}$ S. Alexander, dz. cyt.; C.D. Broad, dz. cyt.

${ }^{41}$ A. Peacocke, P. Clayton, In Whom We Live and Move and Hale Our Being: Scientific Reflection on a Panentheistic Word, Eerdmans Publishing, Grand Rapids 2004.

${ }^{42}$ A.N. Whitehead, Process and Reality. An Essay in Cosmology, The Free Press, New York 1978, s. 346. 
dla prostej koncepcji niezmiennego, wiecznego Boga. Dla zachowania ciągłego i aktualnego odniesienia Boga do świata, przynajmniej pewien Jego aspekt musi być podatny na zmiany w czasie. Whitehead wprowadza tu koncepcje pierwotnej (primordial) i wtórnej (consecutive) natury Boga. O ile ta pierwsza odpowiada z grubsza klasycznym wyobrażeniom o boskiej transcendencji i wszechmocy, o tyle druga wyraża Jego immanencję i zależność bytową od stworzenia $^{43}$. Natura pierwotna stanowi źródło odniesienia do niezmiennych przedmiotów wiecznych i przy odpowiednich założeniach mogłaby stanowić fundamentalny poziom emergencji świata - podstawę wzorców i form proponowanych światu przez odwiecznego Stwórcę. Z kolei natura wtórna jest w całości konstytuowana przez boskie ujęcia wszystkich bytów aktualnych, a zmieniając się wraz z czasem, prowadziłaby do wyłonienia się wiecznotrwałego obrazu Boga na ostatnim szczeblu emergencji stworzenia ${ }^{44}$.

Samuel Alexander przedstawia podobną koncepcję, w której pojmuje on Boga jako „Wszechświat wraz ze swoim wysiłkiem wiodącym do boskości" ${ }^{45}$. Czyni on rozróżnienie na boskie ciało, za które uważa cały świat bytów empirycznych i posiadanych przez nie jakości oraz na boska dusze, czyli wyłaniającą się ze świata jakość bóstwa. Emergentny Bóg jest dla Alexandra Wszechświatem dążącym do boskości. Swoją propozycję nazywa on teizmem immanentnym. Warto wspomnieć, że Ch. Hartshorne, kontynuator procesualnej myśli Whiteheada, również posługuje się metaforą świata, jako Boskiego ciała ${ }^{46}$. Dochodzimy tym samym do wniosku, że koncepcja Boga, a w szczególności zagadnienie jego stwórczej relacji do świata, stanowi jedną z płaszczyzn porozumienia pomię-

\footnotetext{
${ }^{43}$ Szerokie omówienie teologii procesualnej Whiteheada oraz Hartshorne'a znajduje się [w:] J. Życiński, Teizm i filozofia analityczne, tom 2, Znak, Kraków 1988.

${ }^{44} \mathrm{Na}$ radykalnie odmienny sposób istnienia Boga w Jego dwóch aspektach (naturach) wskazują techniczne określenia czasowe: odwieczny (eternal) i wiecznotrwały (everlasting); zob. A.N. Whitehead, dz. cyt., s. 345.

${ }^{45} \mathrm{~S}$. Alexander, dz. cyt., tom II, s. 353.

${ }^{46} \mathrm{Ch}$. Hartshorne, Man's Vision of God and the Logic of Theism, Archont, Hamden 1964.
} 
dzy metafizyką Emergentyzmu Brytyjskiego a filozofią procesu Whiteheada i Hartshorne'a ${ }^{47}$ P. Clayton ${ }^{48}$ zaproponowane przez emergentystów stanowisko nazywa teizmem naturalistycznym lub panenteizmem ${ }^{49}$. Stanowi ono próbę zniesienia napięcia pomiędzy dwoma skrajnościami - teizmem i panteizmem. Posłużymy się tu prostym schematem, który zilustruje różnice między nimi:

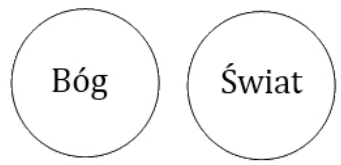

TEIZM

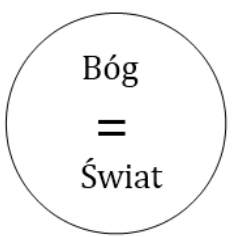

PANTEIZM

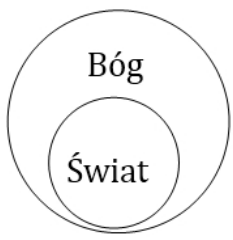

PANENTEIZM

Osobną propozycję ujmowania relacji Stwórca-stworzenie przedstawia J. Życiński, nazywając swoją koncepcję emergentyzmem teistycznym ${ }^{50}$. Autor ten ukazuje przydatność wyjaśnień dostarczanych przez użycie pojęć emergencja, superweniencja, kenoza czy Boży Logos dla „wypracowania spójnej z nauką i filozofią chrześcijańskiej wizji ewolucjonizmu" ${ }^{\prime 1}$. W tej perspektywie uka-

${ }^{47}$ Dla porównania koncepcji Boga i stworzenia w filozofii Alexandra i Whiteheada zob. J. Dziadkowiec, „Tworzenie świata - stwarzaniem Boga. Metafizyka Samuela Alexandra i Alfreda Northa Whiteheada", [w:] M. Czarnuch, J. Oko (red.), Finding Design in Nature? Interdyscyplinarna dyskusja wokól ewolucji, Wydawnictwo Emmanuel, Katowice 2007, s. 15-27.

${ }^{48}$ P. Clayton, „Conceptual Foundations of Emergence Theory”, [w:] P. Clayton, P. Davies (eds.), dz. cyt., s. 1-31.

${ }^{49}$ Wszystkie wymieniane tu przez różnych autorów określenia: teizm temporalny, teizm immanentny, teizm naturalistyczny sugerują koncepcję transcendentnego Boga, który w pewnym aspekcie uwikłany jest w czasoprzestrzenny świat. Za termin wspólny, służący oznaczeniu tego poglądu, przyjmiemy „panenteizm”. Życiński pisze o tym stanowisku następująco: „Uważam jednak, że panenteizm stanowi najbardziej dojrzałą filozoficzną postać doktryny łączącej tezy o Bożej immanencji i transcendencji”; zob. J. Życiński, Teizm..., dz. cyt., s. 150.

${ }^{50}$ J. Życiński, Wszechświat..., dz. cyt., s. 38, 171, gdzie autor zamiennie używa tej nazwy z „naturalizmem chrześcijańskim”.

${ }^{51}$ Tamże, s. 170. 
zywana jest niewystarczalność ujęć redukcjonistycznych w tłumaczeniu genezy psychizmu ludzkiego, moralności, czy problematyki cierpienia i zła, a jednocześnie podkreśla się konieczność filozoficznej i teologicznej afirmacji rezultatów nauk przyrodniczych w poszukiwaniach Boskiego działania w świecie. Interwencje Boga są tu wyrażone przez „różne formy «odgórnego» oddziaływania” oraz przez „przyciąganie” zachodzacych w przyrodzie przemian w stronę Bożych wzorców ${ }^{52}$. Wizja taka stanowi pogodzenie Whiteheadowskiego Poety Świata z doktryną emergencji oraz pozostaje zgodna z podstawowymi prawdami wiary chrześcijańskiej.

Jak widzimy, propozycja emergentnego, panenteistycznego Boga unika skrajnych stanowisk, próbując zachować umiar w ocenie dwóch aspektów relacji Bóg-świat ${ }^{53}$. Za naczelne zadanie stawia ona osiągnięcie wymiaru Boskiego w świecie, a przez to i dopełnienie się samej natury Bożej. Świat jest tutaj zanurzony w Bogu, lecz nie wyczerpuje Jego natury. Jeden aspekt bytu Bożego jest tutaj ujmowany jako fundamentalny poziom ontyczny, który inicjuje i warunkuje proces stworzenia, drugi natomiast jako dopiero mający się wyłonić poziom najwyższy, do którego twórczo zmierza świat. Wykorzystanie relacji emergencji w opisie stosunku Boga do świata prezentuje interesujące możliwości interpretacyjne. Przede wszystkim w relacjach superweniencji i przyczynowania odgórnego zachowane zostaje ciągłe odniesienie Stwórcy do swojego stworzenia. Pierwszy związek wskazuje na fakt, iż każda zmiana $\mathrm{w}$ świecie naturalnym znajduje odniesienie do świata Boskiego. Drugi natomiast gwarantuje Bogu możliwość sprawczego działania w świecie, w którym jest obecny. Z kolei relacja nie-redukowalności pozwala utrzymywać, że Boska rzeczywistość, jakkolwiek częściowo wyłaniająca się z porządku natury,

${ }^{52}$ Tamże, s. 155 .

${ }^{53}$ Zob. R. Niziński, Między teizmem a panteizmem. Charlesa Hartshorne'a procesualna filozofia Boga, Wydawnictwo KUL, Lublin 2002, gdzie autor zderza teizm św. Tomasza z panteizmem Spinozy oraz łączy obydwa w panenteistycznej teologii Hartshorne'a. 
jest do niego niesprowadzalna. Tym samym radykalnie odmienny, transcendentny aspekt natury Bożej zostaje zachowany.

Istnieją zagrożenia płynące z tak zarysowanego stanowiska. Przeakcentowanie znaczenia wtórnej natury Boga może doprowadzić do wykluczenia Go jako czynnika aktualnie działającego w przyrodzie na rzecz siły, która dopiero w niej zaistnieje na odpowiednim szczeblu poziomów emergencji. Bez ciągłego powrotu do koncepcji Boga jako odwiecznego źródła wzorców i form zatracony zostaje Jego stwórczy stosunek do świata. Z drugiej strony odrzucenie tezy, iż przynajmniej pewien aspekt Stwórcy zmienia się wraz z ewoluującą rzeczywistością, niesie niebezpieczeństwo oddalenia Boga od płaszczyzny immanentnej oraz kwestionuje kierunkowy charakter ewolucji emergentnej. W tym kontekście suponowany przez Alexandra wysiłek Wszechświata zmierzający ku wyłonieniu się jakości bóstwa jest tym, co w perspektywie doktryny emergencji nadaje światu sens. Wniosek, uwzględniający także poprzednie rozważania, można sformułować następująco: emergentyzm proponuje wyważoną koncepcje Boga, która pozwala zachować naturalistyczne nastawienie naukowe, a jednocześnie otwiera teleologiczną perspektywę sensownego Wszechświata.

\section{Podsumowanie}

Ustalone zostało, że relacja emergencji posiada swoje dobrze ugruntowane, techniczne znaczenie, które zostało wypracowane w filozoficznym nurcie Emergentyzmu Brytyjskiego oraz we współczesnych debatach nad warunkami emergencji. Obecnie istnieją tendencje do stosowania jej zarówno w różnych gałęziach filozofii (np.: filozofia umysłu, filozofia nauki, filozofia przyrody, filozofia Boga), jak i w interpretacjach rezultatów nauk przyrodniczych. Prezentacja tej drugiej tendencji została ograniczona do zbadania możliwości wykorzystania relacji emergencji w dwóch problemach współczesnej fizyki: w wyjaśnieniu zjawiska dekoherencji w mechanice kwantowej oraz w zagadnieniu początku Wszechświata w kosmologii kwantowej. W obydwu przypadkach emergencja 
dostarcza atrakcyjnych propozycji eksplikacyjnych, które jednak wymagaja dokładniejszych, interdyscyplinarnych badań nad fizycznymi odpowiednikami tej relacji. Z kolei tendencja pierwsza zobrazowana była przez szereg uwag na temat koncepcji panenteistycznego Boga, jaką zawiera - zestawiona tutaj z filozofią procesu - metafizyka emergentna. Wyważona koncepcja częściowo wyłaniającego się Boga daje światu odniesienie do przekraczającej go transcendencji, która nadaje sens temu, co doczesne.

W ten sposób Wszechświat emergentny, w którym różne stopnie złożoności ontycznej charakteryzują się odpowiednio spreparowaną relacją emergencji, stwarza nową przestrzeń interpretacyjną dla słów ks. M. Hellera: „Bóg jest tym, co nadaje sens człowiekowi, historii i światu" ${ }^{54}$. Emergencja Boga jest tym, do czego dąży Wszechświat jako całość. Co więcej, odniesienie do rezultatów badań naukowych pozwala utrzymywać stały związek tej propozycji z wiedzą o świecie przyrody. Natomiast w antropologicznej perspektywie emergencja Boga w życiu osoby jest jej jednostkowym wysiłkiem. W ten sposób człowiek bierze udział w globalnym procesie realizacji Boga, który cierpliwie prowadzi świat przez kolejne poziomy ontycznych struktur rzeczywistości.

\section{Bibliografia}

1. Alexander S., Space, Time, and Deity. The Gifford Lectures at Glasgow 1916-1918, Macmillan and Co., London 1927.

2. Ambjorn J., Jurkiewicz J., Loll R., „3d Lorentzian, Dynamically Triangulated Quantum Gravity", Nuclear Physics Proceedings Supplements, 106 (2002), s. 980-982.

3. Ashtekar A., Bojowald M., Lewandowski J., „Mathematical structure of loop quantum cosmology", Advances in Theoretical and Mathematical Physics, 7 (2003), s. 233-268.

${ }^{54}$ M. Heller, J. Życiński, Wszechświat $i$ filozofia. Szkice z filozofii i historii nauki, Polskie Towarzystwo Teologiczne, Kraków 1980. 
4. Bain A., Logic, Book II \& III, London 1870.

5. Broad C.D., The Mind and Its Place in Nature, Routledge and Kegan Paul, London 1925.

6. Campbell D.T., „'Downward causation' in Hierarchically Organized Biological Systems", [w:] Ayala F.J., Dobzhansky T. (eds), Studies in the Philosophy of Biology, Macmillan Press 1974, s. 179-186.

7. Chalmers D., „Strong and Weak Emergence”, [w:] Clayton P., Davies P. (eds): The Re-Emergence of Emergence. The Emergentist Hypothesis from Science to Religion, Oxford 2006, s. 244-256.

8. Clayton P., „Conceptual Foundations of Emergence Theory", [w:] Clayton P. Davies P. (eds): The Re-Emergence of emergence. The Emergetist Hypothesis from Science to Religion, Oxford 2006, s. 1-31.

9. Clayton P., Davies P. (eds), The Re-Emergence of Emergence. The Emergentist Hypothesis from Science to Religion, Oxford 2006.

10. Davidson D., „Mental Events”, [w:] Foster L., Swanson J.W. (eds): Experience and Theory, Duckworth, London 1970, s. $79-101$.

11. Dziadkowiec J., „Tworzenie świata - stwarzaniem Boga. Metafizyka Samueala Alexandra i Alfreda Northa Whiteheada", [w:] Czarnuch M., Oko J. (red.), Finding Design in Nature? Interdyscyplinarna dyskusja wokół ewolucji, Wydawnictwo Emmanuel, Katowice 2007, s. 15-27.

12. Dziadkowiec J., „Warunki emergencji biologicznej w świetle sporu emergentyzm-redukcjonizm", Roczniki Filozoficzne, LVII (1) (2009), s. 5-27. 
13. Everett H., „'Relative state' Formulation of Quantum Mechanics", Review Modern Physics, 29 (1957), s. 454-462.

14. Feynman R., QED. Osobliwa teoria światta i materii, Państwowy Instytut Wydawniczy, Warszawa 1992.

15. Golbiak J., Poczatek świata w kosmologii kwantowej, rozprawa doktorska, Katolicki Uniwersytet Lubelski, Lublin 2007.

16. Hartle J.B., Hawking S.W., „Wave Function of the Universe", Physics review, D28 (1983), s. 2960-2975.

17. Hartshorne Ch., Man's Vision of God and the Logic of Theism, Archon, Hamden 1964.

18. Heller M., Życiński J., Wszechświat i filozofia. Szkice z filozofii $i$ historii nauki, Polskie Towarzystwo Teologiczne, Kraków 1980.

19. Heller M., Ewolucja kosmosu i kosmologii, PWN, Warszawa 1985 .

20. Heller M., Poczatek jest wszędzie. Nowa hipoteza pochodzenia wszechświata, Prószyński i S-ka, Warszawa 2002.

21. Heller M., Sens życia i sens Wszechświata. Studia z teologii współczesnej, Biblos, Tarnów 2008.

22. Kim J., „Emergence: Core ideas and issues”, Synthese, 151 (2006), s. 547-559.

23. Korn R. W., „The Emergence Principle in Biological Hierarchies", Biology and Philosophy, 20 (2005), s. 137-151.

24. Lewes G.H., The Problems of Life and Mind, vol. 2, Kegan Paul, Trench, Turbner, \& Co., London 1875.

25. McCarthy J., The Naturalism of Samuel Alexander, King's Crown Press, New York 1948. 
26. McLaughlin B., „Emergence and Supervenience”, Intellectica, 25 (2) (1997), s. 25-43.

27. McLaughlin B., „The Rise and Fall of British Emergentism”, [w:] Bedau M., Humphreys P. (eds): Emergence: Contemporary Readings in Philosophy and Science, A Bradford Book, Cambridge 2008, s. 19-59.

28. Metallmann J., Determinizm w biologii, Biblos, Tarnów 2002 .

29. Mill J.S., The System of Logic, Longmans, Green, Reader, and Dyer, London 1872.

30. Morgan C.L., Emergent Evolution, Williams \& Norgate, London 1923.

31. Mścisławski Ł., „Dziwne twierdzenie z teorii kwantów”, Semina Scientiarum, 4 (2005), s. 83-93.

32. Musther H.D., Wprowadzenie do filozofii przyrody, WAM, Kraków 2005.

33. Niziński R., Między teizmem a panteizmem. Charlesa Hartshorne'a procesualna filozofia Boga, Wydawnictwo KUL, Lublin 2002.

34. Peacocke A., Clayton P., In Whom We Live and Move and Have Our Being: Scientific Reflections on a Panentheistic World, Eerdmans, Grand Rapids 2004.

35. Poczobut R., Między redukcja a emergencja. Spór o miejsce umystu w świecie fizycznym, Wydawnictwo Uniwersytetu Wrocławskiego, Wrocław 2009.

36. Seevinck M.P., Parts and Wholes. An Inquiry into Quantum and Classical Correlations, Enschede, Netherlands 2008.

37. Sellars, W., „Is consciousness physical?”, Monist, 64 (1981), s. $66-90$. 
38. Stephan A., „Emergence - A Systematic View on its Historical Facets", [w:] Beckerman A., Flohr H., Kim J. (eds), Emergence or Reduction? Essays on the Prospects of Nonreductive Physicalism, Walter de Gruyter 1992, s. 25-47.

39. Szydłowki M., Golbiak J., „Kwantowa emergencja Wszechświata", VIII Polski Zjazd Filozoficzny, Warszawa 2008; $<$ http://www.kul.lublin.pl/files/57/working_papers/ golbiak_szydlowski_z_2008.pdf>, 12.01.2012.

40. Szydłowski M., Tambor P., Kosmologia współczesna jako efektywna teoria Wszechświata - studium metodologiczne, VIII Polski Zjazd Filozoficzny, Warszawa 2008; <http://www.kul.lublin.pl/files/57/working_papers/szydlowski_tambor_2008f.pdf >, 12.01.2012.

41. Tryon E.P., „Is the Universe a Vacuum Fluctuation?”, Nature, 246 (1973), s. 396-397.

42. Vilenkin A., „Quantum Cosmology and the Initial State of the Universe", Physical Review, D37 (1988), s. 888-897.

43. Whitehead A.N., Process and Reality. An Essay in Cosmology, The Free Press, New York 1978.

44. Życiński J., Teizm i filozofia analityczna, t. 2, Znak, Kraków 1988.

45. Życiński J., Wszechświat emergentny. Bóg w ewolucji przyrody, Lublin 2009.

\section{Abstract}

\section{Searching for Sense in the Emergent Universe}

The relation of emergence finds more and more application areas in philosophical and scientific researches. By displaying its 
sources within the current of British Emergentism and by formulating conditions for that relation, the paper analysis a validity of reference between the concept of emergence and two issues developed by contemporary physics: Copenhagen interpretation of quantum decoherence and the beginning of Universe within selected models of quantum cosmology. Complementally, an idea of emerging God that - entangled in natural world structures confers the sense upon it, is introduced. Such an operation emphasizes a universality of emergence relation in explaining connections between consecutive levels of ontological structures.

Keywords: decoherence, emergence, God, panentheism, quantum cosmology, supervenience 